\title{
Non-Metastatic Brain Neoplasm
}

National Cancer Institute

\section{Source}

National Cancer Institute. Non-Metastatic Brain Neoplasm. NCI Thesaurus. Code C4952.

Brain neoplasm that is confined to the site in which it initially manifested 